\title{
PERAN GENDER SEBAGAI PEMODERASI ETIKA PROFESI, STANDAR AUDIT DAN OPINI
}

\author{
Francisca Amaral Agho Go'o1) dan Aminul Amin 2) \\ Sekolah Tinggi Ilmu Ekonomi (STIE) Malangkuçeçwara \\ Jalan Terusan Kalasan Malang - Jawa Timur - 65124 \\ E-Mail: aminulamin.uns@gmail.com
}

DOI: https://doi.org/10.35606/jabm.v27i2.666

\author{
Akuntansi Bisnis dan \\ Manajemen (ABM), \\ Vol. 27 \\ No. 02 \\ Halaman 12-25 \\ Bulan Oktober, Tahun 2020
}

ISSN 0854-4190

E-ISSN 2685-3965

Tanggal Masuk

3 Juli 2020

Tanggal Revisi

28 September 2020

Tanggal diterima

5 Oktober 2020

\section{Abstract}

The purpose of this study is to examine and analyze the effect of professional ethics and audit standards on audit opinion and gender as moderating and differentiating the application of professional ethics. The sample of this research is the auditors who work at the Public Accounting Firm in Malang City as many as 39 accountants. The analytical method used is Moderated Regression Analysis (MRA) and difference test. The results showed that there was an influence between professional ethics, audit standards and gender on audit opinion. Gender moderates the effect of professional ethics on audit opinion. Furthermore, it was found that there were differences between the male auditors and the female auditors in terms of the application of professional ethics when conducting audits. There are indications that female auditors prefer to apply professional ethics in conducting audits.

Keywords: Professional Ethics; Audit Standards; Gender; Audit Opinion

Abstrak
Tujuan penelitian ini menguji dan menganalisis pengaruh etika profesi dan
standar audit terhadap opini audit serta gender sebagai pemoderasi
sekaligus pembeda penerapan etika profesi.. Sampel penelitian ini adalah
auditor yang bekerja pada Kantor Akuntan Publik di Kota Malang
sebanyak 39 akuntan. Metode analisis yang digunakan adalah Moderated
Regression Analysis (MRA) dan uji beda. Hasil penelitian menunjukkan
bahwa terbukti ada pengaruh antara etika profesi, standar audit dan gender
terhadap opini audit. Gender memoderasi pengaruh etika profesi terhadap
opini audit. Lebih lanjut ditemukan bahwa terdapat perbedaan antara
kelompok auditor pria dengan kelompok auditor wanita dalam hal
penerapan etika profesi ketika melakukan audit. Ada indikasi bahwa auditor
wanita lebih menerapkan etika profesi dalam melakukan audit.

Kata Kunci: Etika Profesi; Standar Audit; gender dan Opini Audit. 


\section{PENDAHULUAN}

Kebutuhan terhadap jasa akuntan publik yang semakin meningkat, menuntut akuntan publik meningkatkan kinerjanya. Opini yang diberikan akuntan publik dipengaruhi etika profesi dan standar audit yang dijalankan. Standar audit merupakan jaminan keyakinan terhadap kualitas audit. Etika profesi adalah norma perilaku yang mengatur hubungan antara auditor dengan kliennya, antara auditor dengan rekannya, dan antara auditor dengan masyarakat (Sedati, Halim, \& Wulandari, 2016). Etika akuntan menjadi isu yang sangat menarik di Indonesia. Hal ini seiring dengan terjadinya beberapa pelanggaran etika yang dilakukan oleh akuntan, baik akuntan independen, akuntan intern perusahaan, maupun akuntan pemerintah.

Dalam menjalankan tugasnya, auditor menggunakan standar audit sebagai pedoman. Bagi masyarakat umum, standar audit merupakan jaminan keyakinan terhadap kualitas hasil audit yang dilakukan auditor (Agoes, 2012). Standar Audit yang telah ditetapkan dan disahkan oleh Institut Akuntan Publik Indonesia (IAPI) terdiri atas sepuluh standar yang dikelompokkan menjadi tiga kelompok besar, yaitu: standar umum, standar pekerjaan lapangan, dan standar pelaporan. Pekerjaan sebagai auditor digeluti oleh pria dan wanita. Auditor pria dan wanita memiliki perbedaan dalam memberikan opini. Kaum pria umumnya tidak menggunakan seluruh informasi yang tersedia, sehingga keputusan yang diambil menjadi kurang komprehensif (Fitriyani, 2013).

Penelitian ini merupakan pengembangan penelitian dari beberapa peneliti terdahulu, antara lain penelitian yang dilakukan oleh Fitriyani (2013) yang memberikan hasil bahwa gender berpengaruh terhadap audit judgment, tekanan ketaatan berpengaruh terhadap audit judgment, kompleksitas tugas berpengaruh terhadap audit judgment, pengalaman auditor tidak berpengaruh terhadap audit judgment. Perbedaan penelitian sekarang dengan penelitian yang dilakukan Fitriyani (2013) terletak pada variabelnya. Penelitian sekarang menggunakan etika profesi dan standar audit sebagai variabel independennya dan gender sebagai variabel pemoderasi. Perbedaan lainnya terletak pada pemilihan populasi. Penelitian sekarang memilih auditor yang bekerja di KAP di kota Malang, sedangkan penelitian Fitriyani memilih auditor yang bekerja di KAP di Semarang. Penelitian ini dilakukan untuk mengetahui pengaruh etika profesi dan standar auditing terhadap opini auditor yang bekerja di KAP di wilayah kota Malang dengan gender sebagai pemoderasi karena gender tidak secara langsung mempengaruhi opini auditor melainkan gender memoderasi pengaruh etika profesi terhadap opini audit.

Penelitian Sedati et al. (2016) menunjukkan bahwa Profesionalisme, etika profesi, dan gender secara simultan berpengaruh signifikan terhadap tingkat materialitas. Perbedaan penelitian Sedati et al. (2016) dengan penelitian sekarang terletak pada pemilihan variabel independen dan dependennya. Penelitian Sedati et al. (2016) menggunakan Profesionalisme, Etika Profesi dan Gender sebagai variabel independennya, dan Tingkat Materialitas dalam Pemeriksaan Laporan Keuangan sebagai variabel dependennya, sedangkan penelitian sekarang menggunakan etika profesi dan standar audit sebagai variabel independennya, opini audit sebagai variabel dependennya dan gender sebagai variabel pemoderasi. 
Penelitian Sukmawati, Herawati, \& Sinarwati (2014) menunjukkan bahwa etika profesi berpengaruh positif dan signifikan terhadap opini auditor, kecerdasan intelektual berpengaruh positif dan signifikan terhadap opini auditor, kecerdasan emosional berpengaruh positif dan signifikan terhadap opini auditor, kecerdasan spiritual berpengaruh positif dan signifikan terhadap opini auditor, etika profesi, kecerdasan intelektual, kecerdasan emosional, dan kecerdasan spiritual secara simultan berpengaruh signifikan terhadap opini auditor. Perbedaan antara penelitian (Sukmawati et al., 2014) dengan penelitian ini terletak pada pemilihan variabelnya.

Penelitian saat ini menggunakan etika profesi dan standar auditing sebagai variabel independen, opini audit sebagai variabel dependen, dan gender sebagai variabel moderasi, sedangkan penelitian Sukmawati et al. (2014) menggunakan etika profesi, kecerdasan intelektual, kecerdasan emosional, dan kecerdasan spiritual sebagai variabel independen. Auditor terdiri dari auditor pria dan wanita, pada penelitian Sukmawati et al. (2014) hanya meneliti pengaruh etika profesi secara keseluruhan terhadap opini auditor padahal etika profesi antara auditor pria dan wanita berbeda, sedangkan pada penelitian ini gender dijadikan sebagai variabel moderasi untuk menguji pengaruh etika profesi terhadap opini audit. Dengan demikian penelitian ini dilakukan dengan tujuan untuk menguji dan menganalisis pengaruh etika profesi dan standar audit terhadap opini audit serta gender sebagai pemoderasi sekaligus pembeda penerapan etika profesi.

\section{TINJAUAN PUSTAKA DAN PENGEMBANGAN HIPOTESIS}

\section{Etika Profesi}

Profesi pada dasarnya memiliki komitmen moral tinggi yang dituangkan dalam bentuk aturan khusus. Aturan khusus tersebut yang akan menjadi pegangan bagi setiap orang yang menjalankan profesi tersebut dan biasanya aturan khusus tersebut disebut etika profesi. Akuntan publik sebagai sebuah profesi juga mempunyai kode etik profesi yang dinamakan Kode Etik Akuntan Indonesia. Kode etik akuntan dapat diartikan sebagai suatu sistem prinsip moral dan pelaksanaan aturan yang memberikan pedoman kepada akuntan dalam berhubungan dengan klien, masyarakat dan rekan seprofesi (Agoes, 2012).

Prinsip etika terdiri atas 8 prinsip yaitu: tanggung jawab profesi, kepentingan umum (publik), integritas, objektivitas, kompetensi dan kehati-hatian profesional, kerahasiaan, perilaku profesional, standar teknis (Agoes, 2012). Etika profesi mempengaruhi opini audit karena etika adalah seperangkat nilai yang mengatur perilaku auditor. Apabila seorang auditor dalam menjalankan tugasnya memegang teguh etika profesi yang telah ditetapkan, maka opini yang dibuat akan sesuai dengan SAK.

\section{Standar Audit}

Standar audit adalah aturan dan prosedur yang harus dipakai dalam penugasan audit. Standar audit mengatur tentang hal-hal seperti independensi dan kompetensi auditor sampai bagaimana cara menerbitkan laporan audit. Standar audit memandu akuntan publik dalam melaksanakan pekerjaan audit sesuai dengan kualifikasi auditor, 
misalnya melakukan perencanaan audit dengan jelas, melaksanakan audit di meja (desk audit) ataupun di lapangan (field audit) dengan, dan melakukan pelaporan audit.

Standar audit yang mengatur tanggung jawab auditor dalam merumuskan suatu opini atas laporan keuangan, mengatur bentuk dan isi laporan auditor yang diterbitkan sebagai hasil suatu audit atas laporan keuangan adalah Standar Audit (SA) 700. Selain itu ada juga SA 705 dan 706 yang mengatur bagaimana bentuk dan isi laporan auditor dipengaruhi ketika auditor menyatakan suatu opini modifikasian atau mencantumkan suatu paragraf penekanan atau suatu paragraf hal lain dalam laporan auditor. Standar auditing mempengaruhi opini audit karena standar auditing menjadi pedoman dan pegangan untuk akuntan publik sehingga kewajiban dan larangan dapat dilakukan dengan baik. Standar audit berfungsi sebagai pengendali secara preventif terhadap kecurangan, kelalaian dan ketidakjujuran sehingga opini yang dibuat auditor akan sesuai dengan SAK.

Standar audit mempengaruhi opini audit karena menjadi pedoman akuntan publik dan berfungsi sebagai pengendali secara preventif terhadap kecurangan, kelalaian dan ketidakjujuran sehingga opini yang dibuat auditor merupakan opini yang jujur dan bertanggung jawab.

\section{Gender}

Kata 'gender' berasal dari bahasa inggris yang berarti jenis kelamin, sebenarnya arti ini kurang tepat karena dengan demikian disamakan dengan pengertian sex yang berarti jenis kelamin (Sari, Zuhdi, \& Herawati, 2012). Pada dasarnya pengertian gender berbeda dengan pengertian jenis kelamin. Membahas gender berarti membahas tentang laki-laki dan perempuan dalam masyarakat. Gender penting dalam profesi karena dalam menjalankan profesi, pria dan wanita memiliki peran dan tanggung jawab masing-masing. Berkaitan dengan opini audit, opini yang diberikan oleh auditor pria berbeda dengan auditor wanita. Hal ini disebabkan karena adanya perbedaan psikologis (Nugraha \& Januarti, 2015). Wanita biasanya memiliki pertimbangan moral yang lebih tinggi daripada pria, oleh sebab itu gender dijadikan sebagai moderasi.

\section{Pengembangan Hipotesis}

\section{Pengaruh Etika Profesi terhadap Opini Audit}

Etika merupakan suatu prinsip moral dan perbuatan yang menjadi landasan bertindaknya seseorang sehingga apa yang dilakukannya dipandang oleh masyarakat sebagai perbuatan yang terpuji dan meningkatkan martabat serta kehormatan seseorang. Auditor harus selalu berpegang teguh pada etika profesi yang telah ditetapkan, sehingga dapat menjadi acuan atau panduan dalam melaksanakan tugas auditnya. Dengan memegang teguh etika profesi, diharapkan tidak terjadi kecurangan antar auditor yang dapat membiaskan hasil pemeriksaan laporanan keuangan yang diaudit (Sedati et al., 2016).

Seorang auditor dalam menjalankan pekerjaannya,dituntut untuk mematuhi etika profesi yang sudah ditetapkan oleh Institut Akuntan Publik Indonesia (Rahmawati \& Hanun, 2015). Etika profesi yang ditetapkan oleh IAPI itu mengikat para anggota IAI dan dapat digunakan oleh akuntan lainnya yang bukan atau belum menjadi anggota IAI (Sofia \& Damayanti, 2017). Dengan diterapkannya etika profesi,maka diharapkan 
seorang auditor dapat memberikan pendapat yang sesuai dengan laporan keuangan yang diterbitkan oleh perusahaan. Dan dengan diterapkannya etika profesi, persaingan yang menjurus pada sikap curang di antara para akuntan dapat dihindari.

$\mathrm{H}_{1}$ : Etika profesi berpengaruh terhadap opini audit

\section{Pengaruh Standar Audit Terhadap Opini Audit}

Standar audit merupakan aturan yang harus dipakai sehingga apa yang dilakukan sesuai dengan aturan yang telah ditetapkan. Dengan diterapkannya standar audit maka akuntan publik dapat melakukan pekerjaan audit sesuai dengan syarat minimal atau kualifikasi auditor, melakukan perencanaan audit dengan jelas, melaksanakan audit di meja (desk audit) maupun di lapangan (field audit) dengan baik karena sudah diatur dalam standar dan melakukan pelaporan audit yang jelas (Agoes, 2012). Standar auditing juga berkaitan dengan pertimbangan yang digunakan dalam pelaksanaan dan laporan audit (Anggel \& Riswandari, 2008). Standar auditing yang ada di Indonesia menggunakan SPAP (Standar Profesional Akuntan Publik) yang berarti bahwa agar pelaksanaan audit berjalan dengan benar, maka auditor harus menguasai dan melaksanakan standar auditing yang termasuk di dalam SPAP (Fauziah, 2013). Standar audit akan menjadi pedoman dan pegangan untuk akuntan publik sehingga kewajiban dan larangan dapat dilakukan dengan baik. Standar audit berfungsi sebagai pengendali terhadap kecurangan, kelalaian dan ketidakjujuran (Agoes, 2012). Dengan demikian, auditor yang taat terhadap standar audit akan memberikan opini sesuai dengan laporan keuangan dan terhindar dari kecurangan, kelalaian dan ketidakjujuran

$\mathrm{H}_{2}$ : Standar audit berpengaruh terhadap opini audit

\section{Pengaruh Gender terhadap Opini Audit}

Gender merupakan salah satu faktor level individu yang turut mempengaruhi opini audit karena opini auditor wanita dan pria dapat berbeda, mengingat adanya perbedaan faktor psikologis (Pasanda \& Paranoan, 2013). Gender dalam hal ini tidak hanya diartikan sebagai perbedaan biologis antara pria dan wanita, tetapi lebih dilihat dari segi sosial dan cara mereka dalam menghadapi dan memproses informasi yang diterima untuk melaksanakan pekerjaannya sebagai auditor (Sari, 2016). Pada umumnya, auditor pria tidak menggunakan seluruh informasi yang tersedia dalam mengolah suatu informasi, sedangkan auditor wanita dalam mengolah suatu informasi cenderung teliti dan lebih lengkap, kemudian dievaluasi kembali informasi tersebut dan tidak gampang untuk menyerah. Auditor wanita selain dalam mengolah suatu informasi cenderung teliti dan lengkap, auditor wanita juga memiliki daya ingat terhadap suatu informasi yang baru lebih tajam dibandingkan dengan auditor pria (Yendrawati \& Mukti, 2015).

$\mathrm{H}_{3}$ : Gender berpengaruh terhadap opini audit

\section{Peran Moderasi Gender terhadap Etika Profesi dan Opini Auditi}

Gender adalah konsep yang mengacu pada peran-peran dan tanggung jawab pria dan wanita yang terjadi akibat perubahan keadaan sosial dan budaya manusia (Mukhtar, 2013). Dalam kaitannya dengan kode etik profesi akuntan, biasanya auditor 
wanita memiliki pemahaman yang berbeda dengan auditor pria (Wibowo, 2010). Pria lebih beresiko melanggar kode etik dibandingkan wanita, karena wanita biasanya cenderung lebih tegas dalam berperilaku etis maupun merespon hal-hal yang berkaitan dengan perilaku tidak etis (Rahayu, 2017). Oleh sebab itu gender digunakan sebagai moderasi dalam penelitian ini. Pemahaman yang berbeda antara auditor pria dan wanita akan berpengaruh terhadap opini yang diberikan.

$\mathrm{H}_{4}$ : Gender memoderasi pengaruh etika profesi terhadap opini audit.

\section{METODE PENELITIAN}

Penelitian ini merupakan jenis penelitian kausalitas, yaitu penelitian yang bertujuan menguji pengaruh suatu variabel terhadap variabel lainnya. Ruang lingkup penelitian ini meliputi bidang auditing, yakni opini audit yang dipengaruhi oleh etika profesi dan standar audit dengan gender sebagai pemoderasi. Tujuan umum penelitian ini adalah menguji pengaruh beberapa variabel independen terhadap variabel dependen dengan melibatkan satu variabel moderasi.

Populasi penelitian ini adalah auditor yang bekerja pada Kantor Akuntan Publik di Kota Malang sebanyak 95 orang. Teknik pengambilan sampel adalah non random dengan menggunakan metode quota sampling. Quota sampling juga disebut judgment sampling dua tahap. Tahap pertama, merumuskan kategori sampel yang akan diteliti, yaitu auditor yang terkait langsung dengan pemberian opini atas laporan keuangan. Tahapan kedua, adalah menentukan kuota dengan cara memilih auditor senior yang terlibat penyusunan opini sebanyak 39 orang.

Variabel dependen dalam penelitian ini adalah opini audit, yaitu pernyataan auditor terhadap kewajaran laporan keuangan klien yang telah diaudit. Opini wajar dibuat jika: a) Bukti audit yang cukup dan tepat. b) Laporan keuangan secara keseluruhan bebas dari kesalahan penyajian material, baik yang disebabkan oleh kecurangan maupun kesalahan. c) Laporan keuangan disusun sesuai dengan kerangka pelaporan keuangan yang berlaku. d) Informasi yang disajikan dalam laporan keuangan adalah relevan, dapat diandalkan, dapat diperbandingkan dan dapat dipahami. e) Pelaksanaan audit berdasarkan standar audit

\section{Variabel Independen $(X)$}

\section{Etika Profesi $\left(\mathrm{X}_{1}\right)$}

Etika Profesi merupakan nilai-nilai tingkah laku atau aturan-aturan tingkah laku yang diterima dan digunakan oleh organisasi profesi akuntan, yang meliputi: kerahasiaan, independensi, tidak menerima imbalan dan bentuk remunerasi lain, tidak menyimpan aset klien, kehati-hatian dan kompetensi profesional, integritas, penilaian awal auditor untuk memutuskan apakah akan menerima klien dan mengidentifikasi mengapa klien membutuhkan audit, hadiah dan keramahtamahan, perilaku profesional.

\section{Standar Audit $\left(\mathrm{X}_{2}\right)$}

Standar audit adalah standar yang ditetapkan dan disahkan oleh IAPI yang terdiri dari standar umum, standar pekerjaan lapangan, dan standar pelaporan beserta interpretasinya, yang meliputi: pemahaman tentang standar audit, penerapan standar 
audit, kepatuhan terhadap standar audit, tanggung jawab auditor, penilaian risiko atas laporan keuangan, tanggapan terhadap risiko atas laporan keuangan, laporan setelah melakukan audit.

\section{Variabel Moderasi $\left(\mathrm{X}_{3}\right)$}

Variabel moderasi dalam penelitian ini adalah gender. Gender dalam penelitian ini dinyatakan dalam variabel dummy. Variabel dummy dalam penelitian ini mempunyai dua nilai, yaitu nilai 1 dan nilai 0 serta diberi simbol D. Nilai $1(D=1)$ untuk kelompok yang mendapat perlakuan sedangkan nilai $0(\mathrm{D}=0)$ untuk kelompok yang tidak mendapat perlakuan. Dalam penelitian ini yang diberikan simbol $D=1$ adalah wanita sedangkan $\mathrm{D}=0$ adalah pria. Indikator dari gender meliputi auditor pria dan auditor wanita

\section{Metode Analisis}

Metode analisis menggunakan Moderating Regression Analysis merupakan aplikasi khusus regresi berganda linear dimana dalam persamaan regresinya mengandung unsur interaksi (perkalian dua atau lebih variabel independen). Metode ini dilakukan dengan menambahkan variabel perkalian antara variabel bebas dengan variabel moderatingnya, sehingga persamaan umumnya adalah sebagai berikut: $Y=a+b 1 X 1+$ $\mathrm{b} 2 \mathrm{X} 2+\mathrm{b} 3 \mathrm{X} 1 \mathrm{X} 2$ dengan $\mathrm{Y}$ adalah opini audit, $\mathrm{X} 1$ adalah etika profesi, X2 standar auditing dan X1 X2 adalah perkalian antara etika profesi dengan standar auditing. Hipotesis moderating diterima jika variabel X1 X2 mempunyai pengaruh signifikan terhadap $\mathrm{Y}$.

\section{HASIL DAN PEMBAHASAN}

Hasil analisis deskriptif yang bertujuan untuk memberikan gambaran umum tentang karakteristik variabel penelitian dioleh dengan menggunakan SPSS dan disajikan pada Tabel 1 berikut ini.

\section{Tabel 1. Hasil Analisis Statistik Deskriptif}

\begin{tabular}{lccccccc}
\hline Variabel & $\begin{array}{c}\text { Jumlah } \\
\text { Pernyataan }\end{array}$ & $\begin{array}{c}\text { Skor } \\
\text { Tertingg } \\
\mathrm{i}\end{array}$ & $\begin{array}{c}\text { Skor } \\
\text { Terenda } \\
\mathrm{h}\end{array}$ & Mean & Median & Modus & $\begin{array}{c}\text { Standa } \\
\mathrm{r} \\
\text { Deviasi }\end{array}$ \\
\hline Etika profesi & 10 & 50 & 32 & 39,57 & 41 & 32 & 5,095 \\
Standar & 8 & 40 & 29 & 33,14 & 32,00 & 32 & 2,746 \\
Audit & 7 & 35 & 26 & 28,74 & 28,00 & 28 & 1,930 \\
Opini Audit & 7 & & & & & & \\
\hline
\end{tabular}

Nilai standar deviasi menunjukan seberapa jauh variasi data. Jika nilai standar deviasi > nilai mean, maka hasil tersebut tidak baik atau heterogen. Sebaliknya, jika nilai standar deviasi < nilai mean, maka hasil tersebut baik atau homogen. Perhitungan pada Tabel 1 menunjukan nilai mean untuk semua variabel > nilai standar deviasi. 


\section{Moderating Regression Analysis (MRA)}

Moderating Regression Analysis berbasis analisis regresi berganda yang mempersyaratkan adanya uji asumsi klasik yang terdiri dari uji normalitas, uji multikolinieritas, uji heteroskedastisitas, dan uji autokorelasi. Hasil uji asumsi klasik disajikan berikut ini.

\section{Uji Normalitas}

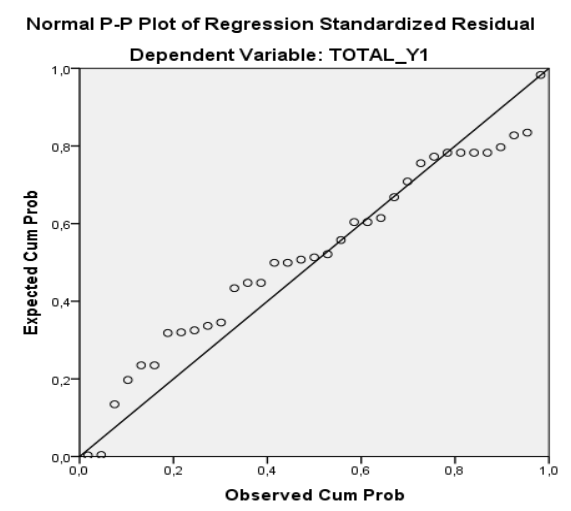

Gambar 1. Hasil uji Normalitas

Hasil uji normalitas data yang ditunjukkan pada gambar 1 merupakan hasil uji normalitas data model ke tiga. Menurut Santoso (2000:346), jika data menyebar di sekitar garis diagonal dan mengikuti arah garis diagonal, maka model regresi memenuhi asumsi normalitas. Sesuai dengan dasar pengambilan keputusan semua variabel memiliki distribusi normal. Gambar scatterplot menunjukan bahwa data menyebar di sekitar garis diagonal dan mengikuti arah garis diagonal. Selanjutnya disajikan hasil uji multikolinearitas pada tabel 2 berikut ini.

Tabel 2. Hasil Uji Multikolinearitas

\begin{tabular}{lcc}
\hline & Model & \multicolumn{2}{c}{ Collinearity Statistics } \\
& Tolerance & VIP \\
(Constant) & & \\
\hline Etika Profesi &, 531 & 1,883 \\
Standar Audit &, 558 & 1,792 \\
Gender &, 909 & 1,100 \\
Etika Profesi*Gender &, 959 & 1,042 \\
\multicolumn{2}{c}{ Dependent Variable: Opini Audit } & \\
\hline
\end{tabular}

Hasil uji multikolinearitas merupakan hasil uji normalitas data model ke tiga. Hasil perhitungan regresi yang dilakukan pada Tabel 2, menunjukkan bahwa nilai tolerance etika profesi adalah $0,531(0,531>0,1)$ dan nilai VIF (Variance Inflation Factor) etika profesi sebesar $1,883(1,883<10)$, nilai tolerance standar audit sebesar $0,558(0,558>$ $0,1)$ dan nilai VIF sebesar $1,792(1,792<10)$. Dari tabel 2 juga dilihat bahwa nilai nilai tolerance gender adalah 0,909 $(0,909>0,1)$ dan nilai VIF (Variance Inflation Factor) gender sebesar 1,100 $(1,100<10)$, nilai tolerance etika profesi ${ }^{*}$ gender sebesar $0,959(0,959$ $>0,1)$ dan nilai VIF sebesar 1,042 $(1,042<10)$. Maka dapat disimpulkan bahwa dalam model regresi tidak ditemukan adanya korelasi antar variabel bebas (independen) dan 
model regresi layak untuk digunakan. Selanjutnya disajikan uji heterosdastisitas yang ditunjukkan pada gambar 2 berikut ini.

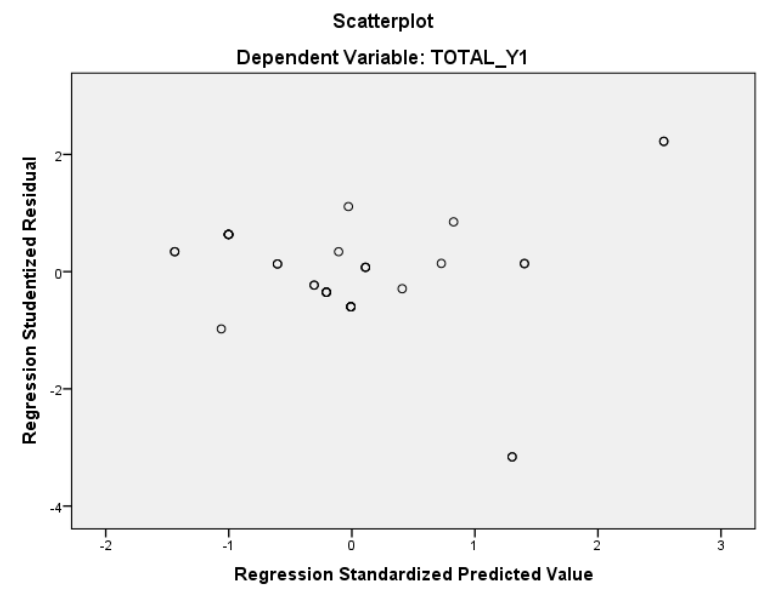

Gambar 2. Hasil Uji Heteroskedastisitas

Sesuai dengan hasil pengujian heteroskedastisitas yang ditunjukka pada gambar 2 dan dengan melihat grafik plot (scatter plot) maka dapat disimpulkan bahwa model regresi ini layak dipakai karena sesuai dengan kriteria pengujian,yaitu penyebaran titik-titik yang ditimbulkan terbentuk secara acak, tidak membentuk suatu pola tertentu dan arah penyebarannya berada diatas maupun dibawah angka 0 pada sumbu Y

\section{Hasil Uji Model MRA}

Uji model MRA menggunakan 3 persamaan (model) yaitu:

1. Persamaan untuk dua prediktor adalah:

$$
Y=a+b_{1} x_{1}+b_{2} x_{2}
$$

2. Persamaan untuk tiga prediktor adalah:

$$
Y=a+b_{1} x_{1}+b_{2} x_{2}+b_{3} x_{3}
$$

3. Persamaan untuk $n$ prediktor adalah:

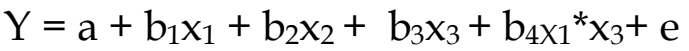

Hasil uji model persamaan 1 disajikan pada Tabel 3 di bawah ini.

Tabel 3. Hasil Uji Model MRA

\begin{tabular}{ccc}
\hline Model & $\mathrm{R}$ & R Square \\
\hline 1 & 0,774 & 0,599 \\
2 & 0,808 & 0,653 \\
3 & 0,845 & 0,713
\end{tabular}

Hasil pengujian MRA model pertama, Nilai R Square sebesar 0,599 sehingga dapat dikatakan bahwa variabel Etika Profesi dan Standar Audit berpengaruh terhadap Opini Audit sebesar 59,9\%. Hasil pengujian MRA model kedua, nilai R Square yang awalnya 0,599 atau 55,9\% meningkat menjadi 0,653 atau 65,3\% sehingga dapat dikatakan bahwa variabel etika profesi, standar audit dan gender berpengaruh 
terhadap opini audit. Hasil pengujian MRA model ketiga dengan menambahkan variabel moderasi (gender) nilai $\mathrm{R}$ Square 0,653 tau 65,3\% meningkat menjadi 0,713 atau $71,3 \%$. Dengan demikian, dapat dikatakan bahwa keberadaan variabel gender sebagai variabel moderasi dapat memperkuat atau meningkatkan pengaruh etika profesi terhadap opini audit.

Uji Independent Sample t Test

Tabel 4

Hasil Uji Independent Sample t Test

\begin{tabular}{ccccc}
\hline Kelompok Gender & N & Mean & $\begin{array}{c}\text { Perbedaan Nilai } \\
\text { Mean }\end{array}$ & Signifikansi \\
\hline Pria & 21 & 3,33 & 0,53 & 0,001 \\
Wanita & 14 & 3,86 & & \\
\hline
\end{tabular}

Berdasarkan Tabel 4 dilihat bahwa nilai sig $<0,05(0,001<0,05)$ ini berarti bahwa terdapat perbedaan antara kelompok auditor pria dengan kelompok auditor wanita dalam hal penerapan etika profesi ketika melakukan audi dan terlihat bahwa auditor wanita lebih menerapkan etika profesi dalam melakukan audit.

\section{Hasil Pengujian Hipotesis}

Hasil pengujian hipotesis yang terdiri dari 4 pernyataan hipotesis disajikan pada Tabel 5 berikut ini.

Tabel 5. Hasil Pengujian Hipotesis

\begin{tabular}{cccccc} 
Variabel & $\begin{array}{c}\text { Ekspektasi } \\
\text { Tanda }\end{array}$ & $\begin{array}{c}\text { Koefisien } \\
\mathrm{b}\end{array}$ & Nilait & Sig & $\begin{array}{c}\text { Keputusan } \\
\text { terhadap } \\
\text { H0 }\end{array}$ \\
\hline Etika Profesi & + & 0,161 & 3,322 & $0,002^{*}$ & H0 ditolak \\
Standar Audit & + & 0,315 & 3,467 & $0,002^{*}$ & H0 ditolak \\
Gender & + & 0,168 & 2,579 & $0,015^{*}$ & H0 ditolak \\
Etika Profesi*Gender & + & 0,045 & 2,514 & $0,018^{*}$ & H0 ditolak \\
\hline Variabel dependen : Opini Audit & & & & \\
*level signifikansi 5\% $(0,05)$ & & & & \\
$* *$ level signifikansi 1\% $(0,01)$ & & & &
\end{tabular}

Tabel 5 menunjukkan bahwa Etika Profesi mempunyai thitung sebesar 3,322 dan $t_{\text {tabel }}$ sebesar 2,037. Jadi $t_{\text {hitung }}>t_{\text {tabel }}$ sedangkan nilai signifikan pada Tabel 9 adalah 0,002 yang lebih kecil dari 0,05 $(0,002<0,05)$. Maka dapat disimpulkan bahwa etika profesi memiliki pengaruh signifikan terhadap opini audit. Standar audit mempunyai nilai $t_{\text {hitung }}$ sebesar 3,467 dan nilai $t_{\text {tabel }}$ yang ada di distribusi $t_{\text {tabel }}$ adalah sebesar 2,037. Jadi $t_{\text {hitung }}>t_{\text {tabel }}$ sedangkan nilai signifikan 0,002 yang lebih kecil dari $0,05(0,002<0,05)$ maka dapat disimpulkan bahwa standar audit berpengaruh terhadap opini audit 
Gender mempunyai nilai nilai $t_{\text {hitung }}$ sebesar 2,579 dan nilai $t_{\text {tabel }}$ yang ada di distribusi $t_{\text {tabel }}$ adalah sebesar 2,037. Jadi $t_{\text {hitung }}>t_{\text {tabel }}$ sedangkan nilai signifikan 0,015 yang lebih kecil dari 0,05 $(0,015<0,05)$ maka dapat disimpulkan bahwa gender berpengaruh terhadap opini audit. Tabel 5 menunjukkan bahwa gender sebagai pemoderasi pengaruh etika profesi terhadap opini audit adalah 2,514 dan $t_{\text {tabel }}$ sebesar 2,037. Jadi $t_{\text {hitung }}>t_{\text {tabel }}$ sedangkan nilai signifikan pada Tabel 9 adalah 0,018 yang lebih kecil dari 0,05 $(0,018<0,05)$, maka dapat disimpulkan bahwa gender memoderasi pengaruh etika profesi terhadap opini audit.

\section{PEMBAHASAN}

\section{Pengaruh Etika Profesi Terhadap Opini Audit}

Etika profesi adalah nilai-nilai tingkah laku atau aturan-aturan tingkah laku yang diterima dan digunakan oleh organisasi profesi akuntan. Aturan tingkah laku yang dimaksud disini adalah aturan tingkah laku yang mengatur hubungan antara akuntan dengan kliennya, hubungan antara akuntan dengan rekan sejawatnya, dan hubungan antara akuntan dengan masyarakat. Etika profesi dibentuk untuk mengikat profesi akuntan secara moral sehingga akuntan dapat bertindak ideal dalam menjalankan profesinya. Prinsip-prinsip etika profesi akuntan mengharuskan akuntan untuk berperilaku sesuai aturan yang telah ditetapkan oleh IAI.

Hasil penelitian ini mendukung hipotesis pertama yang menyatakan bahwa etika profesi memiliki pengaruh signifikan terhadap opini auditor, maka dapat ditarik kesimpulan bahwa etika profesi memiliki pengaruh terhadap opini audit. Auditor yang memegang teguh etika profesi maka opini yang diberikan akan memberikan asuransi (jaminan) terhadap laporan keuangan perusahaan yang berkualitas, kredibel dan handal. Hasil penelitian ini mendukung penelitian sebelumnya yaitu penelitian Sukmawati et al. (2014) dan Nugraheni (2016) yang menemukan bahwa etika profesi berpengaruh secara signifikan terhadap opini auditor.

\section{Pengaruh Standar Audit Terhadap Opini Audit}

Standar audit merupakan aturan yang harus dipakai sehingga apa yang dilakukan sesuai dengan aturan yang telah ditetapkan. Dengan diterapkannya standar audit maka akuntan publik dapat melakukan pekerjaan audit sesuai dengan syarat minimal atau kualifikasi auditor, melakukan perencanaan audit dengan jelas, melaksanakan audit di meja (desk audit) maupun di lapangan (field audit) dengan baik karena sudah diatur dalam standar dan melakukan pelaporan audit yang jelas.

Hasil penelitian ini mendukung hipotesis kedua yang menyatakan bahwa standar auditing memiliki pengaruh signifikan terhadap opini auditor, maka dapat ditarik kesimpulan bahwa standar auditing memiliki pengaruh signifikan terhadap opini auditor karena standar audit berfungsi sebagai pengendali secara preventif terhadap kecurangan, kelalaian dan ketidakjujuran sehingga opini yang dibuat auditor memiliki kualitas dan dapat memberikan kepercayaan kepada pengguna laporan keuangan.

\section{Pengaruh Gender Terhadap Opini Audit}

Berkaitan dengan opini audit, opini yang diberikan oleh auditor pria berbeda dengan auditor wanita. Hal ini disebabkan karena adanya perbedaan psikologis 
(Nugraha \& Januarti, 2015). Wanita biasanya memiliki pertimbangan moral yang lebih tinggi daripada pria. Auditor wanita juga cenderung melihat klien dari sisi emosionalnya, termasuk bahasa tubuh dan isyarat nonverbal dari klien, sedangkan auditor pria tidak terlalu memperhatikan isyarat nonverbal dari klien (Kushasyandita, 2012).

Hasil penelitian ini mendukung hipotesis ketiga yang menyatakan bahwa gender memiliki pengaruh terhadap opini audit, maka dapat ditarik kesimpulan bahwa gender memiliki pengaruh signifikan terhadap opini audit karena gender merupakan merupakan level individu yang turut mempengaruhi opini audit. Opini auditor wanita dan pria dapat berbeda, karena karakteristik khas masing-masing gender dan adanya perbedaan faktor psikologis.

\section{Gender Memoderasi Pengaruh Etika Profesi Terhadap Opini Audit}

Terkait dengan kode etik profesi akuntan, auditor wanita memiliki pemahaman yang berbeda dengan auditor pria (Wibowo, 2010). Wanita pada umumnya memiliki pertimbangan moral yang lebih tinggi daripada pria, pria lebih beresiko melanggar kode etik dibandingkan wanita, karena wanita biasanya cenderung lebih tegas dalam berperilaku etis maupun merespon hal-hal yang berkaitan dengan perilaku tidak etis (Rahayu, 2017). Perbedaan pemahaman mengenai etika profesi antara auditor pria dan wanita menggambarkan bahwa pria dan wanita memiliki pertimbangan-pertimbangan berbeda dalam proses pengambilan keputusan yang bersifat etis (Prayudi, 2017).

Gender yang memoderasi pengaruh etika profesi terhadap opini audit adalah wanita karena penerapan yang lebih baik atas etika profesi dan sifat kehati-hatian dalam menjalankan tugas dibandingkan auditor pria. Auditor wanita menerapkan etika profesi yang baik sehingga opini yang diberikan dapat memberikan asuransi atau penajaminan terhadap kualitas laporan keuangan yang lebih baik pula.

\section{KESIMPULAN DAN SARAN}

Hasil penelitian menunjukkan bahwa etika profesi berpengaruh terhadap opini audit, gender berpengaruh terhadap opini audit, dan gender memoderasi pengaruh etika profesi terhadap opini audit. Gender yang dimaksud dalam penelitian ini adalah karakteristik/sifat gender. Hasil uji beda menunjukan bahwa gender wanita lebih patuh terhadap penerapan etika profesi dalam menjalankan tugas dibanding pria, sehingga berdampak pada penyusunan opini auditor yang lebih baik.

Terkait dengan profesi auditor, hendaknya auditor dalam menjalankan tugas selalu menjunjung tinggi etika profesi yang sudah ditetapkan, sehingga sikap dan tindakan yang menjurus ke pelanggaran etika dalam penugasan audit dapat dihindarkan. Independensi, sebagai bagian etika profesi auditor perlu ditegakkan, hal ini penting agar auditor mampu memberikan opini yang bebas dari tekanan pihakpihak tertentu.

Sementara terkait dengan peluang penelitian yang akan datang, maka penelitian selanjutnya hendaknya mengembangkan variabel moderasi lainnya, untuk melihat lebih dalam pengaruhnya terhadap hubungan etika profesi dan opini audit, misalnya level senioritas auditor. Selain itu peneliti berikutnya juga dapat mengembangkan variabel independen lainnya yang diduga mempengaruhi opini audit seperti opini 
audit tahun sebelumnya, pergantian auditor, pendidikan profesi lanjutan yang diikuti dan sebagainya.

\section{DAFTAR PUSTAKA}

Agoes, S. (2012). Petunjuk praktis pemeriksaan akuntan oleh akuntan publik (Edisi 4). Jakarta: Salemba Empat.

Anggel \& Riswandari, E. (2008). Pengaruh penerapan Standar Audit terhadap reliabilitas laporan audit. Jurnal Akuntansi Bisnis, 1(2), 57-74.

Fauziah, S. (2013). Analisis Pengaruh Ketaatan pada Standar Auditing, Pengalaman Auditor, dan Reputasi Kantor Akuntan Publik (KAP) terhadap Kepuasan Klien. (Skripsi). Universitas Budi Luhur. Jakarta.

Fitriyani, M. (2013). Pengaruh gender, tekanan ketaatan, kompleksitas tugas, dan pengalaman auditor terhadap audit judgment. (Tesis). Universitas Muhammadiyah Surakarta. Surakarta.

Kushasyandita, R. S. (2012). Pengaruh pengalaman, keahlian, situasi audit, etika dan gender terhadap ketepatan pemberian opini auditor melalui skeptisisme profesional auditor (studi kasus pada KAP Big Four di Jakarta). (Skripsi). Universitas Diponegoro, Semarang.

Mukhtar, N. (2013). Menggugat bias gender "para ulama". Journal of Qur'an and Hadith Studies 2(2), 189-208.

Nugraha, A. P., \& Januarti, H. I. (2015). Pengaruh gender, pengalaman, keahlian auditor, dan tekanan ketaatan terhadap auditor judgment dengan kompleksitas tugas sebagai variabel moderasi pada BPK RI Jawa Tengah. Jurnal Akuntansi Diponegoro, 4(4), 42-52.

Nugraheni, F. A. (2016). Pengaruh etika profesi, pengalaman kerja, independensi dan keahlian audit terhadap ketepatan pemberian opini auditor. (Skripsi). Universitas Muhammadiyah Surakarta, Surakarta.

Pasanda, E., \& Paranoan, N. (2013). Pengaruh gender dan pengalaman audit terhadap audit judgment. Jurnal Akuntansi Multiparadigma, 4(3), 330-507.

Prayudi, M. A. (2017). Gender, penerapan kode etik profesi akuntan dan kualitas penyusunan anggaran pendapatan dan belanja daerah. Jurnal Ilmiah Akuntansi dan Bisnis, 12(2), 1-8.

Rahayu, S. (2017). Pengaruh gender, pengetahuan etika profesi akuntan, dan jenis perguruan tinggi terhadap persepsi mahasiswa akuntansi mengenai creative accounting. (Skripsi). Universitas Negeri Yogyakarta. Yogyakarta. 
Rahmawati, I. D., \& Hanun, N. R. (2015). Pengaruh profesionalisme dan etika profesi terhadap pertimbangan tingkat materialitas Akuntan Publik. Jurnal Sains Akuntansi, 1(1), 63-81.

Santoso, S. (2000). Buku latihan SPSS statistik parametrik. Jakarta: PT Elex Media Komputindo.

Sari, Zuhdi, R., \& Herawati, N. (2012). Tafsir perilaku etis menurut mahasiswa akuntansi berbasis gender. Jurnal akuntansi Multiparadigma, 3(1), 1-160.

Sari, I. P. (2016). Pengaruh gender, tekanan ketaatan, kompleksitas tugas, pengalaman auditor, pengetahuan auditor dan kompleksitas dokumen audit terhadap audit judgement (studi empiris pada Badan Pemeriksa Keuangan RI Pusat). JOM Fekon, 3(1), 2008-2022.

Sedati, L., Halim, A., \& Wulandari, R. (2016). Pengaruh profesionalisme, etika profesi, dan gender terhadap tingkat materialitas dalam pemeriksaan laporan keuangan (Studi empiris pada Kantor Akuntan Publik di Malang). Journal Riset Mahasiswa Akuntansi (JRMA), 20(20), 1-14.

Sofia, I. P., \& Damayanti, R. T. (2017). Pengaruh pengalaman, profesionalisme, dan etika profesi auditor terhadap penentuan tingkat materialitas. Widyakala, 4(2), 70 $-79$.

Sukmawati, N. L. G., Herawati, N. T., \& Sinarwati, N. K. (2014). Pengaruh etika profesi, kecerdasan intelektual, kecerdasan emosional, dan kecerdasan spiritual terhadap opini auditor. e-Journal S1 Ak Universitas Pendidikan Ganesha Jurusan Akuntansi Program S1, 2(1), 1-11.

Wibowo, E. (2010). Pengaruh gender, pemahaman kode etik profesi akuntan terhadap auditor judgement. Media Akuntansi Unimus, 1(1), 1-10.

Yendrawati, R., \& Mukti, D. K. (2015). Pengaruh gender, pengalaman auditor, kompleksitas tugas, tekanan ketaatan, kemampuan kerja dan pengetahuan auditor terhadap audit judgement. Jurnal Inovasi dan Kewirausahaan, 4(1), 1-8. 